\title{
Use of Colour Etching in the Structural Analysis of Graphitic Cast Irons
}

\author{
Alan Vaško, Juraj Belan, Eva Tillová
}

Department of Material Engineering, Faculty of Mechanical Engineering, University of Žilina. Univerzitná 8215/1, 01026 Žilina. Slovakia. E-mail: alan.vasko@fstroj.uniza.sk, juraj.belan@fstroj.uniza.sk, eva.tillova@fstroj.uniza.sk

Colour metallography, especially colour etching, is a widely used technique for visualizing different phases in the structure of metals. Its advantage to the traditional etching techniques is that it gives additional information about the structure of material. The paper deals with the structural analysis of graphitic cast irons with a focus on colour etching. The possibilities of extending information about the structure of cast irons using colour contrast compared to classic black-and-white contrast is discussed. The paper is supplemented by photographs of microstructures of graphitic cast irons, obtained using classic black-and-white methods, as well as colour etching. Colour photographs of the structure of cast irons were obtained using the light metallographic microscope Neophot 32 with a digital camera Nikon DS-Fi3. Selected etchants for traditional black-and-white etching and for colour etching were used.

Keywords: Structural analysis, Colour metallography, Colour etching, Etchant, Graphitic cast iron

\section{Introduction}

Light metallographic microscopy is the oldest but still the most widespread and most used experimental technique for studying the structure of metals and their alloys. It is based on observation and photographic documentation of the internal structure of metals and alloys, obtained by the reflection of light rays from a specially prepared surface of flat metallographic cuts. In the classic concept of this methodology, a black-and-white contrast between structural microlocalities is used to distinguish structural components. The information obtained by light metallographic microscopy can in many cases be significantly extended by using the colour contrast of structural components. Colour contrast can be further enhanced by using available accessories of the light metallo- graphic microscope or by surface treatment of metallographic specimens [1].

Colour metallography uses the colour contrast (colour difference) between various phases regardless of a specific colour. For example, the blue-yellow contrast is certainly more expressed than the usual dark gray-light gray contrast. Moreover, it is often possible to obtain a colour contrast where it is not possible to obtain an identifiable phase contrast by conventional (black-and-white) methods. Thus new information about the structure are available, while completely accurate colour reproducibility is not essential.

A set of metallographic methods that use the colour contrast of structural components as a source of new information about the structure is presented in Fig. 1. Colour etching is the most important way for developing colour contrast in metallographic microscopy, therefore the following text deals with it [2].

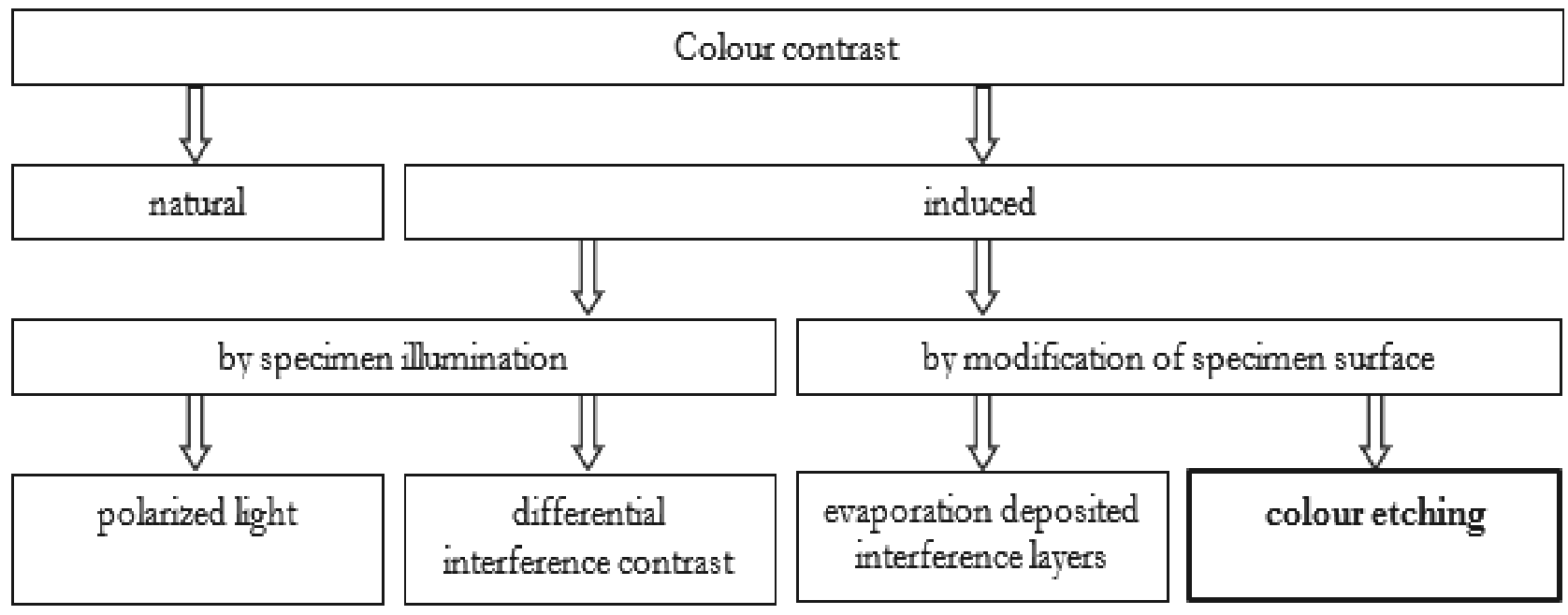

Fig. 1 Different alternatives for developing colour contrast in metallography 
The use of colour contrast in the structural analysis of graphitic cast irons is relatively little used, because the basic structural components can be distinguished even using classic black-and-white metallography $[3,4]$. Nevertheless, the basic methods of developing and enhancing colour contrast are known and summarily described in the technical literature [5-10]. The paper is focused on the use of colour contrast in the structural analysis of graphitic cast irons and the subsequent possibilities of extension of information about the structure in comparison with classic methodologies.

\section{Experimental material and methods}

For structural analysis, specimens of graphitic cast irons were used. Metallographic analysis of the specimens, including colour etching, was carried out on the light metallographic microscope Neophot 32 with a digital camera Nikon DS-Fi3 and software NISElements AR 4.20.
Selected etchants for etching graphitic cast irons are listed in Tab. 1. The etchant is chosen according to the type of examined material and according to the purpose of examination. The basic etchant is Nital; in the case of heat-treated cast irons, suitable etching is achieved using picric acid. Sodium picrate is a classic etchant for developing the primary structure of cast iron based on the segregation of phosphorus and other elements; it is used to distinguish a phosphidic eutectic. Sodium chromate is sensitive to the segregation of main alloyed elements; its use to enhance the macrostructure is suitable for all types of cast iron. Etchant Klemm I is suitable for etching graphitic cast irons which are characterised by segregation of main alloying elements dissolved in austenite or ferrite. Etchant Beraha-Martensite is used to distinguish bainite from martensite in isothermally heat-treated nodular cast irons (referred to ADI) which may contain martensite, bainite and retained austenite (ausferrite), or carbides $[11,12]$.

Tab. 1 Etchants for graphitic cast irons

\begin{tabular}{|c|c|c|}
\hline Etchant & Composition & Use \\
\hline $1 \%$ Nital & $\begin{array}{l}1.6 \mathrm{ml} \text { nitric acid } \\
99.4 \mathrm{ml} \text { ethanol }\end{array}$ & $\begin{array}{l}\text { microstructure in general, ferritic } \\
\text { and ferrite-pearlitic matrix }\end{array}$ \\
\hline $4 \%$ Nital & $\begin{array}{l}6.4 \mathrm{ml} \text { nitric acid } \\
93.6 \mathrm{ml} \text { ethanol }\end{array}$ & $\begin{array}{l}\text { microstructure in general, pearlite- } \\
\text { ferritic matrix, phosphidic eutec- } \\
\text { tics }\end{array}$ \\
\hline Picric acid & $\begin{array}{l}4 \mathrm{~g} \text { picric acid } \\
100 \mathrm{ml} \text { ethanol }\end{array}$ & $\begin{array}{l}\text { microstructure in general, pearlitic } \\
\text { and bainitic matrix }\end{array}$ \\
\hline Stead & $\begin{array}{l}10 \mathrm{~g} \text { copper chloride } \\
40 \mathrm{~g} \text { magnesium chloride } \\
20 \mathrm{ml} \text { hydrochloric acid } \\
\text { the rest up to } 100 \mathrm{ml} \text { ethanol }\end{array}$ & eutectic cell boundaries \\
\hline Murakami & $\begin{array}{l}5 \mathrm{~g} \text { potassium ferrocyanide } \\
25 \mathrm{~g} \text { potassium hydroxide } \\
70 \mathrm{ml} \text { distilled water }\end{array}$ & phosphidic eutectics \\
\hline Sodium picrate & $\begin{array}{l}25 \mathrm{~g} \text { sodium hydroxide } \\
5 \mathrm{~g} \text { picric acid } \\
75 \mathrm{ml} \text { distilled water }\end{array}$ & $\begin{array}{l}\text { macrostructure of cast irons, } \\
\text { phosphidic eutectics (colour) }\end{array}$ \\
\hline Sodium chromate & $\begin{array}{l}35 \mathrm{~g} \text { sodium hydroxide } \\
5 \mathrm{~g} \text { chromium oxide } \\
100 \mathrm{ml} \text { distilled water }\end{array}$ & $\begin{array}{l}\text { macrostructure of quality types of } \\
\text { cast irons (colour) }\end{array}$ \\
\hline Klemm I & $\begin{array}{l}100 \mathrm{ml} \text { of basic solution Klemm } \\
\text { (saturated aqueous solution of so- } \\
\text { dium thiosulphate) } \\
2 \mathrm{~g} \text { potassium pyrosulphite }\end{array}$ & $\begin{array}{l}\text { segregation of main elements, e.g. } \\
\text { silicon and manganese (colour) }\end{array}$ \\
\hline Beraha-Martensite & $\begin{array}{l}2 \mathrm{~g} \text { potassium pyrosulphite } \\
2 \mathrm{~g} \text { ammonium hydrogendifluoride } \\
100 \mathrm{ml} \text { of basic solution BWI } \\
\text { ( } 5 \text { parts distilled water }+1 \text { part hy- } \\
\text { drochloric acid) }\end{array}$ & $\begin{array}{l}\text { distinction between bainite and } \\
\text { martensite (colour) }\end{array}$ \\
\hline
\end{tabular}

\section{Experimental results and discussion}

For developing the macro and microstructure of graphitic cast irons, some of the etchants presented in Tab. 1 were used. The microstructure of two types of graphitic cast irons etched by conventional etchants 
for black-and-white contrast is shown in Fig. 2. Both cast irons were etched by Nital and picric acid. The structure of lamellar cast iron (Fig. 2a) etched by $1 \%$ Nital consists of ferrite (white colour), pearlite (gray) and lamellar graphite (black) with a uniform distribution. The structure of nodular cast iron (Fig. 2b) consists of ferrite, perlite and nodular graphite. The use of picric acid did not provide any new information about the structure.

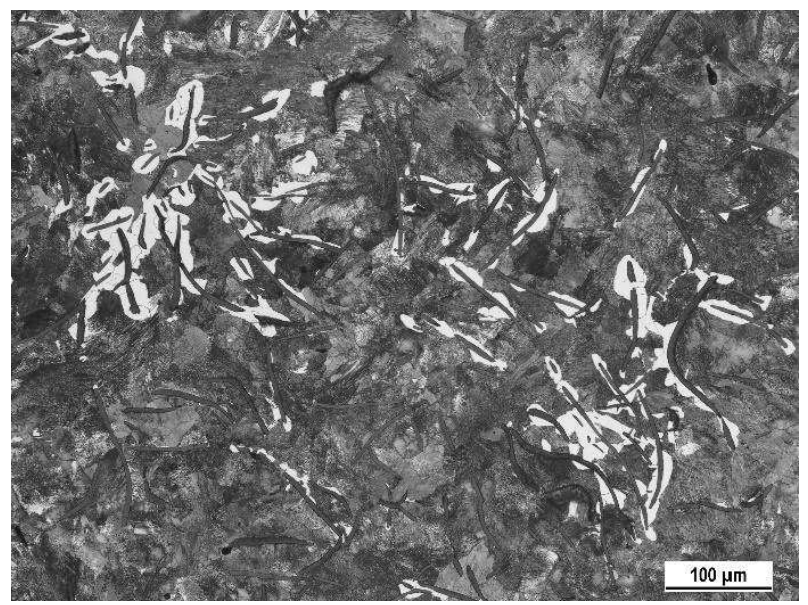

a) pearlite-ferritic lamellar cast iron

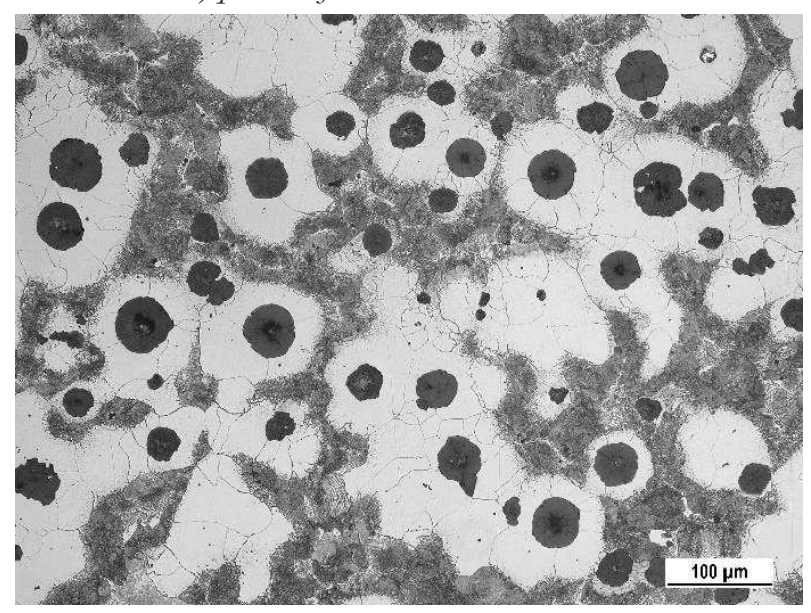

b) ferrite-pearlitic nodular cast iron

Fig. 2 Microstructure of graphitic cast irons in black-andwhite contrast, etched by $1 \%$ Nital

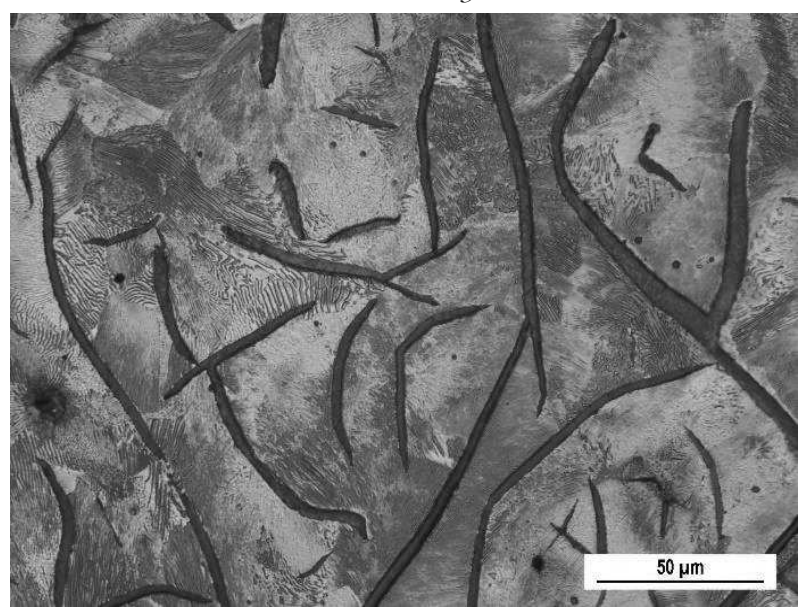

a) lamellar cast iron, etched by sodium chromate

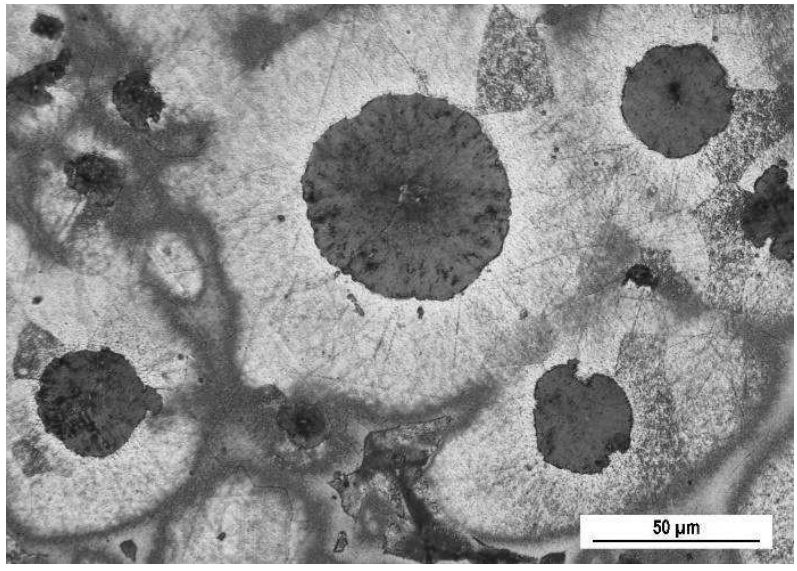

b) nodular cast iron, etched by sodium chromate

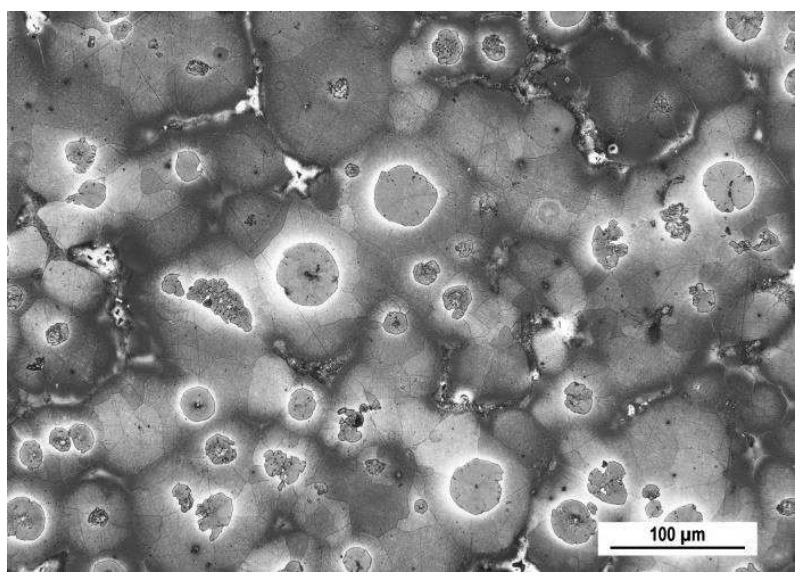

c) nodular cast iron, etched by Klemm I

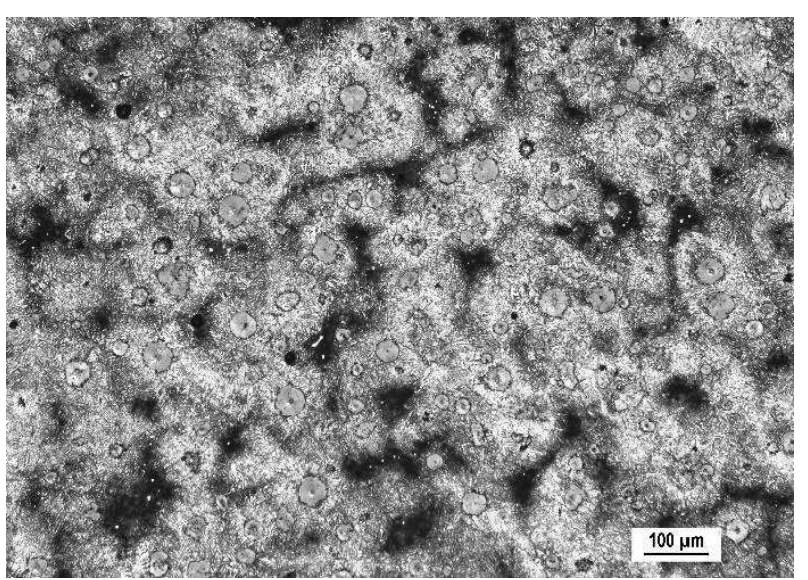

d) ADI, etched by Beraha-Martensite

Fig. 3 Microstructure of graphitic cast irons in colour contrast

Examples of the use of colour etchants are shown in Fig. 3. Lamellar cast iron etched by sodium chromate (Fig. 3a) has a colour contrast formed by a spectrum of colours from light yellow through red to brown. The matrix is yellow-red, with the red colour indicating the boundaries of eutectic cells. In nodular cast iron etched by sodium chromate (Fig. 3b), a spectrum of colours from white through light blue and dark blue to brown was observed. There is a light blue ferrite around the graphitic particles, the pearlitic part 
of the matrix is brown. After etching by Klemm I (Fig. $3 c)$, the colour of the matrix changes from white through light brown and dark brown to blue, which is caused by the segragation of main elements, dissolved in ferrite. Silicon content is the highest near graphitic particles (white colour) and lowest on the boundaries of eutectic cells (blue colour). The segregation of manganese is inverse; the lowest content is near graphitic particles and highest content on the boundaries of eutectic cells. ADI (austempered ductile iron) was etched by Beraha-Martenzit (Fig. 3d). Martensite is coloured blue, bainite (ausferrite) is red-brown and retained austenite is white.

\section{Conclusions}

The colour contrast between microlocalities extends in many cases the potentiality of light metallographic microscopy. It enables to differentiate the phases (eventually the marked segregation in a solid solution) which are differentiated with great difficulty when using the black-and-white contrast, or it is not possible to differentiate them at all. This is the main contribution of using the colour contrast method in metallography.

The colour etching of metallographic specimens enables mainly to accentuate the differences in the chemical composition of microlocalities, therefore it is suitable for the study of segregation phenomena, heataffected zones, diffusion layers and for differentiation of phases with markedly different chemical composition.

The use of colour contrast in metallography is an available experimental methodology for every metallographic laboratory and it may extend and deepen the level of current metallographic analysis.

\section{Acknowledgement}

The research has been supported by grant projects VEGA No. 1/0398/19 and KEGA No. $012 \check{Z} U-4 / 2019$ and $016 \check{Z} U-4 / 2020$.

\section{References}

[1] SKOČOVSKÝ, P., PODRÁBSKÝ, T. (2001). Colour metallography of ferrous alloys, EDIS, Žilina. ISBN 80-7100-911-3.
[2] SKOČOVSKÝ, P. (1993). Colour contrast in metallographic microscopy, Slovmetal, Žilina. ISBN 80-966996-1-X.

[3] KOVÁČIKOVÁ, P., VAVRO, J., DUBEC, A. (2018). Microstructure evaluation of ductile cast iron and numerical modal analysis. In: $M a-$ nufacturing Technology, Vol. 18, No. 4, p. 597-599. ISSN 1213-2489.

[4] KOVÁČIKOVÁ, P., DUBEC, A., VAVRO, J. (2019). Microscopic evaluation of cast iron with flake shape of graphite. In: Manufacturing Technology, Vol. 19, No. 4, p. 609-612. ISSN 12132489.

[5] VANDER VOORT, G. F. (2010). Metallography - Principles and Practice, ASM International, Materials Park, USA. ISBN 978-0-87170-672-0.

[6] PETZOW, G. (1999). Metallographic Etching Techniques for Metallography, Ceramography, Plastography, ASM International, Materials Park, USA. ISBN 0-87170-633-4.

[7] VANDER VOORT, G. F. (2004). Color metallography. In: ASM Handbook, Volume 9: Metallography and microstructures, pp. 493-512. ASM International, Materials Park, USA. ISBN 9780-87170-706-2.

[8] RADZIKOWSKA, J. M. (2004). Metallography and microstructures of cast iron. In: ASM Handbook, Volume 9: Metallography and microstructures, pp. 565-587. ASM International, Materials Park, USA. ISBN 978-0-87170-706-2.

[9] RADZIKOWSKA, J. (2000). Color etching in foundry metallography. In: Advanced Materials and Processes, Vol. 157, No. 2, pp. 29-32. ISSN 0882-7958.

[10] ZHOU, J. (2009). Colour metallography of cast iron. In: China Foundry, Vol. 6, No. 1, pp. 57-69. ISSN 1672-6421.

[11] SKOČOVSKÝ, P., VAŠKO, A. (2007). Quantitative evaluation of structure of cast irons, EDIS, Žilina. ISBN 978-80-8070-748-4.

[12] KONEČNÁ, R., FINTOVÁ, S. (2014). Methods of structure study I, EDIS, Žilina. ISBN 978-80554-0943-6. 